and other on-site measurements, automatic weather stations are being set up. Measurements will be fed into a small computer to monitor the accuracy of the instruments and calculate the average values from the individual measurements, taken every half minute. Data will be recorded on a punched tape for analysis.

A new area of study is the physical and biological processes controlling evaporation from forests. Very little is now known of the process except that it is complicated, so the institute is setting up a detailed experiment in Thetford, Norfolk, where there is a very large forest planted in the early thirties and now reaching a height of 50 feet. Two instrument towers are being built to measure wind speed, air temperature and humidity at five heights, as well as radiation, leaf temperatures, soil moisture and rainfall. Because extensive work has already been done on evaporation from low vegetation-grass and arable crops-this new study will enable the situation in the catchment areas to be estimated from a combination of the two extremes.

\section{Rose-coloured Syrup}

The complacency of the annual report of the Ministry of Health for 1967 (price 23s.) hardly seems justifiable in view of the many difficulties which have become apparent in many branches of the British Health Service. The indispensability of this service is selfevident, but, at the same time, it is equally obvious that a long hard look needs to be taken to see how its present functioning could be improved, for it is far from perfect.

According to the report, last year "saw progress on almost every front in the health services", and value for money was a chief consideration. Expenditure amounted to $£ 1,358$ million in the financial year which ended on March 31, 1967. This represented an increase over the previous financial year of $£ 117$ million and accounted for about one-ninth of total public expenditure by the central Government and local authorities. The total can be broken down in the following way:

$\begin{array}{lr}\text { Central administration } & £ 7 \text { million } \\ \text { Hospitals } & £ 765 \text { million } \\ \text { General medical } & £ 97 \text { million } \\ \text { Local Health Authority } & £ 126 \text { million } \\ \text { Pharmaceutical } & £ 142 \text { million } \\ \text { Others } & £ 221 \text { million }\end{array}$

Following the increase in remuneration in 1966, no general improvements in remuneration for hospital medical and dental staff were made in 1967, but the number of distinction awards was increased. General practitioners were a little more fortunate, for a new system of remuneration was brought fully into operation on April 1, according to which payments are made for night visits, immunization, vaccination and so on. This new scheme, it is hoped, will increase the attractiveness of general practice as a career. Interest-free loans to doctors were discontinued on May 31 but a scheme was approved to assist general practitioncrs in the financing of practice premises (the General Practice Finance Corporation).

Not surprisingly, the number of prescriptions rose by 3.5 per cent compared with 1966 , and the cost rose by $5 \cdot 7$ per cent. 1,539 doctors were visited by the ministry's Regional Medical Officers because of high prescribing costs. Baroness Serota was appointed chairman of the new Health Education Council in November. Fourteen new health centres were opened as were 121 new homes for elderly people, providing accommodation for 5,322 residents.

The number of hospital beds available at December 31 was 467,447 - a fall of 848 compared with the previous year. The number of patients treated in hospital, however, increased by 114,000 . The report welcomes the relatively small increase of patients waiting for admission to hospital, but the waiting lists for surgical departments $(415,513)$ and gynaecology $(83,297)$ cannot really be regarded as satisfactory. In August the Government announced that it would make available the finance necessary to establish a new medical school at Southampton University, the need for which is emphasized by the fact that the provisional figure of 2,431 British-based students accepted for medical school in 1967 is only slightly higher than the number $(2,312)$ in 1966.

\section{Money for Booms}

Compensation of $\mathfrak{k} 3,200$ has so far been paid by the Ministry of Technology for the damage caused by the four sonic boom tests carried out over London last summer with Lightning aircraft. The other seven tests over other parts of Britain cost just over $£ 700$ in compensation. The minister has promised a full report on the tests "shortly", which by all accounts means not before the next session of Parliament in October. Until the report appears, the number and details of the claims that have been settled are being withheld, but all were referred by the Ministry of Technology to the Claims Commission of the Ministry of Defence-a body with experience of and machinery for adjudicating and settling claims for damage resulting from military activities. With onc exception, all the claims involved damage to property. The exception was a claim made by a woman from Hornchurch who suffered a partial loss of hearing as a result of a sonic boom and accepted $£ 150$ settlement.

Even before the tests, the British Government seems to have recognized that aircraft should not be allowed to fly at supersonic speeds over densely populated areas. On June 19 last year, for example, Lord Beswick told the House of Lords that the Concorde will not reach supersonic speeds until 100 miles after take-off. It seems inevitable that all supersonic flight over land will be prohibited, at least until a great deaI more information on the effect of sonic booms has been collected. Last year's tests should not have had any influence on that decision. The Minister of Technology himself admitted their irrelevancy when he said on July 21 last year that the sonic booms heard in London during the tests were not comparable to those which could be expected from the Concorde. And eleven tests can hardly be said to have justified the ministry's much more modest claim that "we have achieved the object of informing people about the nature of a supersonic bang". In the United States, where much more extensive tests have been made, the National Academy of Sciences-National Rescarch Council Committee on supersonic transport and the sonic loom concluded that with the currently available data it is just not possible accurately to assess the type and amount of damage that sonic booms can cause (see Nature 217, $1101 ; 1968)$. The makers of the Concorde certainly 
anticipate a complete ban on overland supersonic flight. That is perhaps the most realistic factor in their calculations, which lead them to say they will sell two hundred Concordes by 1975.

\section{Mr Healey on Top}

THE Secretary of State for Defence has been at his job for much longer than the Select Committee on Science and Technology. The difference in experience was clear when Mr Healey gave evidence to the committee last week. For a bluff and cheerful two hours, $\mathrm{Mr}$ Healey instructed the committee on the ins and outs of defence research. It was an impressive performance-helped, it must be conceded, by some indifferent questioning from the committee.

Mr Healey started by explaining that the withdrawal of British forces from the Far East is unlikely to save money for research and development, since very little of the work is explicitly designed for that part of the world. The research expenditure is likely to remain about 11 per cent of the total defence budget. Collaboration, once achieved, could give savings, but the total cost of the project would be up by about 20 per cent. Defence research could only be justified by defence needs, not by any appeal to the benefits it might bring to the civil field. But the Far East withdrawal did mean that Britain's defence needs were now more closely identified with those of Europe, which should make collaboration easier. Mr Healey was unimpressed by the suggestion that there were large areas of research which could be put out to industry. For one thing, he said, most of the problems were those industry had no interest in solving, and there would in any case be a continuing need for the work to be monitored, so that some expertise would have to be retained by the ministry. The easiest way of doing this was by keeping the establishments open. In any case, Mr Healey doubted whether the staff redeployed would move quickly into industry-people tended to be far too optimistic about this, he said.

Later, Mr Healey denied that the organization of the Ministry of Defence was "a jungle". It was more like a well planned garden, he said, though it was unfamiliar "to those who strayed in from the surrounding countryside". To those who claimed that the organization chart was too complicated, Mr Healey recommended opening the back of a transistor radio; although it looked complicated, it was really very simple, he suggested. In this, Mr Healey found an unexpected ally in Mr Tam Dalyell, who believes that time spent on organizational details is time wasted. Mr Healey was also doubtful of the value of the building bloek concept of defence procurement. This idea, which Mr David Price put forward, holds that if defence procurement is based on existing technology without building into the specification the need for extensive research and development, it is cheaper and more effective. Mr Healey doubted that it would be cheaper; the US F111 aircraft, made on the building block approach, had cost $£ 400$ million, without taking into account the costs of the building blocks themselves, while the cost of the TSR2, built by the British approach, would have been $£ 300$ million. The US system was "appallingly expensive", he said. And although there might be some delays in the British system, it was nothing like as bad as people suggested.

\section{Parliament in Britain}

\section{by our Parliamentary Correspondent}

\section{British Museum}

Mr BOYD-CARPENTER asked the Prime Minister why no consultation had taken place between him and the Standing Commission on Museums and Galleries before the Government announcement that the British Museum Library could not be built in Bloomsbury. Mr Wilson said that the consultation would have been between the standing commission and the Secretary of State for Education and Science, but that $\mathrm{Mr}$ Gordon-Walker had not thought the subject of such direct concern as to make advance consultation necessary. Mr Wilson added that he was grateful to Lord Rosse, chairman of the commission, for agreeing to help the Dainton Committee in its work. It was, he agreed, arguable whether or not Lord Rosse should have been consulted. (Oral answer, July 16.)

\section{Defence Research}

Mr GerRy ReYnolds, for the Ministry of Defence, said that by the end of March 1971 the numbers of scientists and other professional grades employed in defence work would be reduced by 6 per cent compared with numbers previously planned for that year, and by 4.5 per cent compared with present numbers. (Written answer, July 16.)

\section{Power Stations}

Mr Roy Mason, the Minister of Power, told Mr Arthur Palmer that he was setting up a committee to investigate delays in the commissioning of power stations. The terms of reference were: "To enquire into the causes of delays in commissioning CEGB power stations, and measures to remedy them, and to make recommendations about any further action that may be required". The chairman of the committee is to be Sir Alan Wilson, Chairman of the Glaxo Group and Deputy Chairman of the Electricity Council, and there will be five other members. The committee would keep in touch with the NEDC working party on large industrial construction sites, in order to eliminate unnecessary duplication. It is noteworthy that the committee's brief refers only to the CEGB, and not to the Scottish boards. (Written answer, July 17.)

\section{Computers}

DR Jeremy Bray, for the Ministry of Technology, gave a breakdown of the $£ 11.6$ million which the Government has authorized in support of the British computer industry. The Science Research Council spends $£ 2.5$ million per year, and the National Research Development Corporation $£ 3 \cdot 0$ million (excluding $£ 4$ million lent to ICL). The Ministry of Technology has a ceiling of $£ 2 \cdot 6$ million on the Advanced Computer Technology Project, $\mathfrak{2 2 . 5}$ million on the Atlas Computer Aided Design Centre at Cambridge, $£ 0.5$ million on university research contracts and another $\mathfrak{£} 0.5$ on UKAEA sponsored work. Dr Bray also gave details of the total spent in support since the beginning of computing. It includes $£ 6 \cdot 6$ million from NRDC, and $£ 1.08$ million spent so far of the money allocated to the Advanced Computer Technology Project. But these totals do not include the cost of work in government establishments, or expenditure for military purposes, and application projects and computer purchases are also excluded. (Written answer, July 18.) 